\title{
Fundatio Orzelkoviana. A Contribution to the History of Scholarship Foundations in Polonia Maior During the Old Polish Period
}

\begin{abstract}
Most of articles on patronage in Greater Poland from the 16th to the 18th century concerns a direct dependence between the patron and the client. Thus, the present work concentrates on a specific kind of patronage - scholarship foundations, which are only briefly mentioned in historiography. Some of them are not known. "Fundatio orzelkoviana" serves as an example here to show the need for detailed relevant case studies to supplement the available data. Founded by Marcin Orzel in 1566, the foundation existed for many years and helped young people to achieve academic education. Ius patronatus and control of the foundation was assigned to the Catedral Chapter of Poznań. Admittedly, this Chapter was interested in keeping the foundation in good condition, e. g. by being aware of economic and financial factors influencing the foundation and by carrying out the recovery in debts, be it rents or fees. The source material for the present discussion comes from the Main Archive for Poznan Archdiocese (mainly the acts of the Cathedral Chapter of Poznań, Consistory Court and the canonical visitation of Bishop Tholibowski).
\end{abstract}

Keywords: foundation, Marcin Orzeł, Poznań, history of eduacation

One of the main characteristics of Renaissance education, was the existence of patronage, often essential for achieving success in this aspect, by people coming from the "lowest social classes" . Patronage would assume different forms ${ }^{2}$, with one of them being the scholarship foundation dedicated to locating a particular fund, providing particular rent in particular periods of time. It is understandable that such form of support was quite bene-

1 The aim of the article is solely to signal the research possibilities regarding the scholarship foundations in the XVI-XVIII centuries in Polonia Maior. The source material used to present the issue is not exhausting, therefore, for the complete perspective, an archive query is necessary, especially regarding the archive sets mentioned below.

2 See: RYBICKI, P., Odrodzenie, [in:] Historia nauki polskiej, vol. 1, ed. B. SUCHODOLSKI, WrocławWarszawa-Kraków 1970, p. 237-239. 
ficial and gave testament to the providence of the patron, as it guaranteed longevity, however under the risk of the fund devaluation. One should also note the fact, that such form of patronage could be charitable, but also devotional ${ }^{3}$.

The existence of patronage in Polonia Maior in modernity has received some attention $^{4}$. However, there is still no detailed and comprehensive monograph regarding scholarship foundations ${ }^{5}$. The 1566 foundation created by Marcin Orzeł, a plebanus of Strzelce seems particularly interesting, however, it received but a few remarks in literature ${ }^{6}$. The majority of source material on the subject is available in the Archdiocesan Archive in Poznań, in the records of the Cathedral Chapter of Poznań7, as well as the records of the Poznań Consistory ${ }^{8}$. Interesting information may also be found within the Canonical Visitation of bishop Wojciech Tholibowski in 1660-16639.

According to the contents of the records of proceeding of the Chapter, Martinus Orlius, a plebanus in Strzelce near Gostyń, in the presence of gathered prelates and canons during the General Chapter, somewhere around saint Martin's memorial, 1566, expressed the will of granting 1200 złotys with a rent of 89,5 grzywnas, i.e. 143 złotys and 6 Polish

${ }^{3}$ Regarding the theoretical model of patronage, see: DMITRUK, K. M., Wokót teorii i historii mecenatu, [in:] Z dziejów mecenatu kulturalnego w Polsce, ed. J. KOSTECKI, Warszawa 1999, where (p. 29) we read : "Particular activities of the patron are adequate to his social role. From an individual perspective the behaviour of the patron is sign of his personal traits and are considered as merit. In reality however, the aforementioned activities are entangled in a complex network of situations, closely related to the status of the patron".

${ }^{4}$ See. particularly: SAJKOWSKI, A., Życie kulturalne $w$ XVI $i$ w pierwszej połowie XVII w., [in:] Dzieje Wielkopolski, vol. 1: Do roku 1793, Poznań 1969, p. 574-581; p. 599-605.

5 BUCHWALD-PELCOWA, P., Mecenat nad piśmiennictwem i książka w dawnej Polsce, [in:] Z dziejów mecenatu kulturalnego w Polsce, ed. J. KOSTECKI, Warszawa 1999, p. 37 noticed that patronage is usually perceived in an individual manner, as a relation between the patron and the pupil. The author noted that "rarely [...] does one consider the group, 'collective', institutional yet not always completely formal patronage". As examples for such cases, the author lists scholarship funded not only by private entities, but also cities. An interesting work regarding the scholarship foundations in Gdańsk, was published by: KOTARSKI, E., Fundacje stypendialne w dawnym Gdańsku, [in:] Fundacje i fundatorzy w średniowieczu i epoce nowożytnej, ed. E. OPALIŃSKI and T. WIŚLICZ, Warszawa 2000. Such foundations in Polonia Maior received only a small number of remarks, e.g.: KRYGIER, R., Szamotulanie znani i mniej znani: wybór biogramów, Szamotuły 1992, p. 162.

${ }^{6}$ See: ŁUKASZEWICZ, J., Historya szkół $w$ Koronie $i w$ Wielkiem Księstwie Litewskiem od najdawniejszych czasów aż do roku 1794, vol. 3, Poznań 1851, p. 501 et al.; MAZURKIEWICZ, K., Benedykt Herbest: pedagog-organizator szkoty polskiej XVI wieku, kaznodzieja-misjonarz doby reformacji, Poznań 1925, p. 160 et al.; SKORUPSKA, Z., Życie umysłowe i literackie do 1793 r., [in:] Dziesięć wieków Poznania, vol. 2: Kultura umysłowa, literatura, teatr i muzyka, Poznań-Warszawa 1956, p. 23; ŁABĘDZKA-TOPOLSKA, M.D., Życie umystowe i rozwój kultury, [in:] Dzieje Poznania, vol. 1: Do roku 1793, ed. J., TOPOLSKI, Warszawa-Poznań 1988, p. 508; p. 514; NOWACKI, J., “Akademia Lubrańskiego”, Kronika Miasta Poznania, 1999, no. 2: Jan Lubrański i jego dzieło, p. 172.

${ }^{7}$ Akta czynności kapituly poznańskiej, Archiwum Archidiecezjalne w Poznaniu (later cited as AAP), sign. CP 41-62; Liber Racienscianus, AAP, sign. CP 17.

${ }^{8}$ Akta konsystorza poznańskiego 1559-1567, AAP, sign. AC 121.

${ }^{9}$ Akta wizytacji 1660-1663, AAP, sign. AV 12. 
groszes ${ }^{10}$. The appropriate foundation was, seemingly, established before the Poznan Consistory on 8 November of the same year, i.e. at the time of the aforementioned General Chapter. It is possible that it was established on the very same day. An appropriate record in the files was titled Donatio et ordinatio certarum summarum Ecclesiae in maiori Strzelcze per honestem Martinum Orzel facta ${ }^{11}$. The economic base for the foundation consisted of an arrangement of goods listed in the Poznań Castle court files, which provided income, as shown in the table below ${ }^{12}$.

Table 1

\begin{tabular}{|c|c|l|}
\hline $\begin{array}{c}\text { Date of record } \\
\text { in castle court files }\end{array}$ & capital sum & \multicolumn{1}{|c|}{ goods } \\
\hline 1566 & 200 złotys & Pogorzel \\
1566 & 200 złotys & Radzeno, Młyny Konarskie \\
1557 & No data & Morka, Jelenczewo, Bielewo, Strzelce \\
1588 & No data & Bodzieiewo maior, Mchy \\
1588 & 100 złotys & Widziszewo \\
1559 & 200 złotys & Krzyżanowo, Zgierzyce \\
1562 & 200 złotys & Krzypno, Wola, Momoty \\
\hline
\end{tabular}

Obviously, such comparison does not demonstrate the changes that occurred within the foundation. However, the fact that it was completed in the middle of the $17^{\text {th }}$ century, tells that the earnings were relatively stable. An examination of all the translations of the earning sums is possible due to a meticulously kept book of records, titled Liber Racienscianus $^{13}$.

The disposition of Marcin Orzel foundation is quite vast and detailed, providing information regarding the assignment of the income from particular goods to serve particular aims. The foundation included, e.g. the vicars, the minister ecclesiae and the hospital of Strzelce $^{14}$. Additionally, provisions were dedicated to poor women, both young and adult ${ }^{15}$, however in this case, the disposition did not provide details regarding the particular purpose of the funds. In terms of education, a bequest of 10 grzywnas yearly for one scholar ${ }^{16}$,

${ }^{10}$ Akta czynności kapituly 1560-1567, sign. CP 41, f. 49; rent conversion rate according to: Akta wizytacji $1660-1663$, p. 110.

${ }^{11}$ Akta konsystorza poznańskiego 1559-1567, f. 1080-1081v.

12 Based on Akt wizytacji 1660-1663, p. 110.

${ }^{13}$ Liber Racienscianus, f. 72-74. Here we provide further references to the appropriate Poznań Castle court files.

${ }^{14}$ Akta czynności kapituly 1560-1567, f. 49v.

${ }^{15}$ Akta konsystorza poznańskiego 1559-1567, f. 1081.

${ }^{16}$ Akta czynności kapituly 1560-1567, f. 50: pro uno scholari studioso singulis annis marc. 10. Liber Racienscianus, f. 74 and 81; Akta konsystorza poznańskiego 1559-1567, f. 1081. 
who is to be an adolescent man (adolescens) continuing his education at a chosen university, is particularly interesting ${ }^{17}$. The provision was to be paid in subsequent years; as practice shows, required an attestation of the student's diligence ${ }^{18}$. Administration over the foundation was turned over to the General Chapter of Poznan, and the Chapter was allowed to choose the candidates for the scholarship. However, information whether the Chapter received some sort of gratification for the aforementioned, could not be found. The 1660/1663 visitation files contain information, that 31 złotys were bequested on the rent vindicator ${ }^{19}$. As the vindication task was often committed to the provisors, one can assume, that the gratification was meant for the provisor of the foundation.

The fact, that the Cathedral Chapter ensured the proper functioning of the foundation is clearly visible in the aforementioned records of proceeding. The foundation is a regular subject of the Chapter, the case of "Orzelkoviana" is disputed along with the diocese seminar (1609 and 1610 $)^{20}$. The Chapter would dispute the general care of the foundation and its related earthly goods ${ }^{21}$ as well as accounting matters ${ }^{22}$. The presentation and choice of the scholarship candidates are a different matter. The acts show that the Chapter made use of the presentations of students, made by people outside of the Chapter. Characteristically, in the $17^{\text {th }}$ century, it was the professors from the Lubrański Academy ${ }^{23}$. Moreover, on 30 June 1628 the Chapter issued a decree that in favorem eiusdem Domini Directoris [i.e. the Lubrański Academy Director - M.N.], studioso quicunque per eum in Capitulo praesentatus fuerit Marcas decem pro studiis ex fundatione Orzełkoviana per D. Provisorem eiusdem fundationis extradere... ${ }^{24}$. In that manner, the Orzełkoviana was closely tied to the aforementioned academic school. Among the presentation formulas, one may note e.g. ad petitione Excellentis D. Magistri Golinski Professoris... ${ }^{25}$, ad interresione Adreae Gulcewski... ${ }^{26}$, „the members of the Chapter habentes commendatam personam decided..."27. The social stand-

17 Akta konsystorza poznańskiego 1559-1567, f. 1081: pro studiis ad aliqua universitate.

${ }_{18}$ Akta wizytacji 1660-1663, p. 111: Studioso ex Universitate approbata testimonium diligentiae dandi Flor 16.

19 Akta wizytacji 1660-1663, p. 111.

${ }^{20}$ Akta czynności kapituly 1602-1615, AAP, sign. CP 49, f. 298, 329.

${ }^{21}$ E.g. in July 1621 two people were chosen from among the canons to ensure the translation of the income sums between goods, see: Akta czynnności kapituly 1619-1624, AAP, sign. CP 50, f. 164.

22 Akta czynności kapituly 1619-1624, f. 200, 313 , 387 et al.

${ }^{23}$ NOWACKI, J., “Akademia Lubrańskiego", p. 172 mentioned the relation between the Orzełkoviana and the Lubrański Academy. However, despite his excellent knowledge regarding the acts of the Cathedral Chapter, he was unable to show whether any individuals outside of the Lubranscianum school, since the reinstatement of its study, were clients of the foundation.

\footnotetext{
24 Akta czynności kapituly 1624-1634, AAP, sign. CP 51, f. 214 et al.

25 Akta czynności kapituly 1619-1624, f. 213.

${ }^{26}$ Akta czynności kapituly 1619-1624, f. 338.

27 Akta czynności kapituly 1624-1634, f. 301.
} 
ing of the students was not described within the foundation. Members of Polish nobility were among the clients, e.g. in 1623, a student named Krajewski was granted scholarship due to the efforts of the canon, Andrzej Gulczewski ${ }^{28}$.

The foundation appears in the acts under several similar names: ordinatio Orzetek ${ }^{29}$, fundatio Orzełek ${ }^{30}$, fundatio Orzełkoviana ${ }^{31}$. Its financial condition is worth examining. In November 1621, appropriate accounts were presented, showing that the foundation possessed a sum of 372 złotys and 16 groszes, from which 104 złotys were deducted as expenditures, however the object of expenditures was not presented ${ }^{32}$. In the following year, the income with the sum from the year 1621 amounted to 373 złotys and 16 groszes, however a much bigger sum of 219 złotys and 6 groszes was spent ${ }^{33}$. If in 1623 the income was on a similar level (108 złotys due to the rent), only one scholarship was given, for the noble Krajewski in a sum of 16 złotys $^{34}$.

Due to the efficient allocation of funds in many goods, which ensured the stability of rent income, the foundation was able to function for a long time. Complications arose in the midst of the $17^{\text {th }}$ century. In 1652 , the account shows, that the income surpassed the expenditures by 144 złoty and 29 and a half groszes. However, in the subsequent year as well as in 1654, no accounts were presented, despite the presence of a provisor of the foundation at the General and Particular Chapters also during the plague. Furthermore, when Polonia Maior was taken over by Swedish forces, the provisor perished in 1656 in Trojanów. He was the Poznań Cathedral canon Marcin Krajewski ${ }^{35}$ (could it be that he was the client of the foundation in 1623 and 1624?).

Concerning the Orzełkoviana foundation, numerous questions, and further research postulates arise, that should be indicated. Primarily, in order to possess a detailed view of the foundation, it is necessary to conduct a precise query within acts of proceeding of the Cathedral Chapter, allowing to establish a list of individuals supported by the foundation, including their social standing. Furthermore, it would be interesting to establish the frequency of academic leaves and localisations frequented by the students, and particularly, their further career development. A question arises whether the students addressed the Chapter, asking for further support. Is there any correspondence left, giving testimony to such practice. Based on the inventory of the Archdiocesan Archive in Poznan, one can say that there are no such traces left.

${ }^{28}$ Akta czynności kapituly, 1619-1624, f. 338, according to accounts of the foundation (f. 387) Krajewski received 16 złotys. The scholarship was given again for the year 1624 (see: f. 417). The acts contain no name of the student.

\footnotetext{
29 Akta czynności kapituly 1602-1615, f. 298.

${ }^{30}$ Akta czynności kapituly 1619-1624, f. 213, 227, 338.

${ }^{31}$ Akta czynności kapituly 1624-1634, f. 214 et al.

32 Akta czynności kapituly 1619-1624, f. 200 et al.

33 Akta czynności kapituly 1619-1624, f. 313.

34 Akta czynności kapituly 1619-1624, f. 387 et al.

${ }^{35}$ Akta wizytacji 1660-1663, p. 109.
} 
Another important issue is the continuity of the functioning of the aforementioned scholarship foundation. The Cathedral Chapter decree of November 1736, reminding that in the light of the law and the Canonical Visitation of Tholibowski, the foundation still exists and its belonging sums are to be vindicated, suggests that for some time the foundation must have been suspended or simply forgotten ${ }^{36}$. The very process of reinstating the foundation "to life" must have been difficult, as for subsequent years the Chapter would appoint their own rent vindicators ${ }^{37}$. In 1755 a decision was made to establish a memorandum concerning the foundation ${ }^{38}$. It seems that its reinstatement could occur around 1758. Then, the provost of the church of Strzelce was appointed to collect due sums and deliver the money for the students and impoverished women to Poznan ${ }^{39}$.

Fundatio orzelkoviana is an exceptional foundation. Established by the donation of a patron whose social standing was not exceptionally high ${ }^{40}$, and what is more important, was not dedicated to a limited group of the founder's siblings ${ }^{41}$, but to the general populace of the poor youth striving to continue their education ${ }^{42}$. Appropriate endowment allowed the foundation to function for a long time, surely enabling to educate a significant number of students. One could also notice the role of the Cathedral Chapter of Poznan whose understanding for the educational needs of youth was clear. In this case, however, the period of inactivity regarding the dispositions of Marcin Orzeł remains in question.

${ }^{36}$ Akta czynności kapituly 1727-1745, AAP, sign. CP 59, f. 272v.

${ }^{37}$ One could risk identifying the vindicator with the provisor-caretaker of the foundation.

${ }^{38}$ Akta czynności kapituly 1746-1756, AAP, sign. CP 60, f. 355: Chapter of 18 August 1755.

39 Akta czynności kapituly 1757-1766, AAP, sign. CP 61, f. 40. One should point out that vindicators were already appointed (within the Cathedral Chapter), however they were probably unable to vindicate the due sums. A query directed at the economic aspects of the Chapter should provide answers to these matters.

${ }^{40}$ Referring to the theory by: DMITRUK, K.M., Wokót teorii i historii mecenatu, p. 29 et. al. One should note, that surely the position of Marcin Orzeł within the social structure, in no way forced him to fulfil certain public obligations.

${ }^{41}$ One can find many such foundations in Polonia Maior. A bequest of eight thousand zlotys from inherited goods by Krzysztof Wodzyński, a Poznań, Płock and Pułtusk Cathedral Canon, as well as a plebanus of Latowicz, included in the testament of 1683 may serve as an example (Liber testamentorum primus 15471695, AAP, sign. CP 85, f. 187) pro fundationis Studiosorum de linea paterna vel materna. See also: Fundatio Cielecciana for 10 students from the Cieleccy family from a scholarship of $30 \mathrm{zł}$ given quarterly for education in the Lubrański Academy or the Jesuit College (Liber privilegiorum F 1629-1659, AAP, sign. CP 6, f. 265v272, especially f. 279) or Noskoviana (Visitatio Ecclesiae Cathedralis Posnaniensis per... Okęcki 1781-1784, AAP, sign. CP 97, p. 86 et al.).

42 Regarding the meaning of education, e.g. within the urban environment of Poznań, see: MIKA, M. J., Studia nad patrycjatem poznańskim $w$ wiekach średnich, re-edition, Poznań 2006, passim. Particularly interesting is the model, described by the author, provided by the patricians via the tradition of pursuing education, e.g. in Kraków. University education was also significant in the ecclesial circles of Poznań. Additionally see: ŻOŁĄDŹ, D., Ideały edukacyjne doby staropolskiej. Stanowe modele i potrzeby edukacyjne szesnastego i siedemnastego wieku, Warszawa-Poznań 1990, p. 49 as wall as: Eadem, "Możliwości i potrzeby edukacyjne mieszczan polskich w XVI i XVII wieku”, Rozprawy z Dziejów Oświaty, 1990, 33, p. 29, where the benefits of educating the middle class were highlighted. 
The above brief glimpse regarding the fate of the Orzełkoviana foundation helps realise the necessity of conducting further studies concerning the history of scholarship foundations in Polonia Maior in Old Poland. Precise studies, based on the studies of the archives, not yet sufficiently exploited. An interesting example may be given to support that claim, regarding a scholarship found related to Kościan, that is yet to receive mention in monographs dedicated to this city ${ }^{43}$. In 1612 Bartłomiej Grzech, the Magister of liberal arts personally stood before judge Marcin Moręski, presenting him a privilege to engross, regarding fundationis Domini Praepositi S. Spiritus in Costen pro duobus Adolescentibus Costensibus in Academia Cracoviensi Artibus liberalibus operam navantibus, written in the Poznań Castle Court ${ }^{44}$. The foundation was secured with a sum of three-hundred grzywnas, from which a yearly rent of twenty grzywnas was to be deduced, for the disposition of the Magistrate of Kościan pro duobus adolescentibus Costensibus ingenuis et Catholicis, popularibus suis in Alma Academia Cracoviensi duntaxat: vel per Germaniam in Academii externis si facultas permiserit, liberalibus artibus operam navantibus ${ }^{45}$. A vast disposition of this privilege provides an in triguing view of its functioning, and should serve as an assumption for further pursuits especially in regard of the Kościan Castle Court. In general, one can state that the research regarding the scholarship foundations within the Polonia Maior in the aforementioned period is appropriate and would indubitably prove as a valuable addition to the knowledge regarding the history of education.

\section{Bibligraphy}

Akta czynnności kapituły 1619-1624, Archiwum Archidiecezjalne w Poznaniu, sygn. CP 50. Akta czynności kapituły 1560-1567, Archiwum Archidiecezjalne w Poznaniu, sygn. CP 41. Akta czynności kapituly 1602-1615, Archiwum Archidiecezjalne w Poznaniu, sygn. CP 49. Akta czynności kapituly 1624-1634, Archiwum Archidiecezjalne w Poznaniu, sygn. CP 51. Akta czynności kapituly 1727-1745, Archiwum Archidiecezjalne w Poznaniu, sygn. CP 59. Akta czynności kapituly 1746-1756, Archiwum Archidiecezjalne w Poznaniu, sygn. CP 60. Akta czynności kapituly 1757-1766, Archiwum Archidiecezjalne w Poznaniu, sygn. CP 61. Akta konsystorza poznańskiego 1559-1567, Archiwum Archidiecezjalne w Poznaniu, sygn. AC 121. Akta konsystorza poznańskiego 1613-1618, Archiwum Archidiecezjalne w Poznaniu, sygn. AC 137. Akta wizytacji 1660-1663, Archiwum Archidiecezjalne w Poznaniu, sygn. AV 12.

BUCHWALD-PELCOWA, P., Mecenat nad piśmiennictwem i książka w dawnej Polsce, [in:] Z dziejów mecenatu kulturalnego w Polsce, ed. J. KOSTECKI, Warszawa 1999.

DMITRUK, K.M., Wokół teorii i historii mecenatu, [in:] Z dziejów mecenatu kulturalnego w Polsce, ed. J. KOSTECKI, Warszawa 1999.

KOTARSKI, E., Fundacje stypendialne w dawnym Gdańsku, [in:] Fundacje i fundatorzy w średniowieczu i epoce nowożytnej, ed. E. OPALIŃSKI and T. WIŚLICZ, Warsaw 2000.

KRYGIER, R., Szamotulanie znani i mniej znani: wybór biogramów, Szamotuły 1992.

${ }^{43}$ The founder appears in: WIELGOSZ, Z., Kościan w epoce przedrozbiorowej (do roku 1793), [in:] Kościan. Zarys dziejów, ed. Z. WIELGOSZ, K. ZIMNIEWICZ, Warszawa-Poznań 1985, p. 11-102; Idem, Życie umysłowe oraz kultura późnego średniowiecza i renesansu, [in:] Historia Kościana, vol. 1: Okres staropolski, ed. K. ZIMNIEWICZ, Kościan 2005, p. 221.

\footnotetext{
${ }^{44}$ Akta konsystorza poznańskiego 1613-1618, AAP, sign. AC 137, f. 112v-121.

45 Akta konsystorza poznańskiego 1613-1618, f. 114.
} 
Liber privilegiorum F 1629-1659, Archiwum Archidiecezjalne w Poznaniu, sygn. CP 6.

Liber Racienscianus, Archiwum Archidiecezjalne w Poznaniu, sygn. CP 17.

Liber testamentorum primus 1547-1695, Archiwum Archidiecezjalne w Poznaniu, sygn. CP 85.

ŁABĘDZKA-TOPOLSKA, M.D., Życie umysłowe i rozwój kultury, [in:] Dzieje Poznania, vol. 1: Do roku 1793, ed. J. TOPOLSKI, Warsaw-Poznań 1988.

ŁUKASZEWICZ, J., Historya szkół w Koronie i w Wielkiem Księstwie Litewskiem od najdawniejszych czasów aż do roku 1794, vol. 3, Poznań 1851.

MAZURKIEWICZ, K., Benedykt Herbest: pedagog-organizator szkoły polskiej XVI wieku, kaznodzieja-misjonarz doby reformacji, Poznań 1925.

MIKA., M., Studia nad patrycjatem poznańskim w wiekach średnich, (re-edition) Poznań 2006.

NOWACKI, J., "Akademia Lubrańskiego”, Kronika Miasta Poznania 1999, No. 2: Jan Lubrański i jego dzieto.

RYBICKI, P., Odrodzenie, [in:] Historia nauki polskiej, vol. 1, ed. B. SUCHODOLSKI, WrocławWarsaw-Kraków 1970, p. 237-239.

SAJKOWSKI, A., Życie kulturalne w XVI $i$ w pierwszej połowie XVII w., [in:] Dzieje Wielkopolski, vol. 1: Do roku 1793, Poznań 1969.

SKORUPSKA, Z., Życie umystowe i literackie do 1793 r., [in:] Dziesięć wieków Poznania, vol. 2: Kultura umystowa, literatura, teatr i muzyka, Poznań-Warsaw 1956.

Visitatio Ecclesiae Cathedralis Posnaniensis per ... Okęcki 1781-1784, Archiwum Archidiecezjalne w Poznaniu, sygn. CP 97.

WIELGOSZ, Z., Życie umysłowe oraz kultura późnego średniowiecza i renesansu, [in:] Historia Kościana, vol. 1: Okres staropolski, ed. K. ZIMNIEWICZ, Kościan 2005.

WIELGOSZ, Z., Kościan w epoce przedrozbiorowej (do roku 1793), [in:] Kościan. Zarys dziejów, ed. Z. WIELGOSZ, K. ZIMNIEWICZ, Warsaw-Poznań 1985.

ŻOŁĄDŹ, D., "Możliwości i potrzeby edukacyjne mieszczan polskich w XVI i XVII wieku", Rozprawy z Dziejów Oświaty 1990, 33.

ŻOŁĄDŹ, D., Ideały edukacyjne doby staropolskiej. Stanowe modele i potrzeby edukacyjne szesnastego i siedemnastego wieku, Warsaw-Poznań 1990.

Originally published in "Biuletyn Historii Wychowania", 2010, vol. 26, pp. 81-86 